\title{
Nitrate Reduction in a Reconstructed Floodplain Oxbow Fed by Tile Drainage
}

Keith E. Schilling ${ }^{1 *}$, Keegan Kult ${ }^{2}$, Karen Wilke ${ }^{3}$, Matthew Streeter ${ }^{1}$, Jason Vogelgesang ${ }^{1}$

${ }^{1}$ Iowa Geological Survey, Trowbridge Hall, University of Iowa, Iowa City, IA

${ }^{2}$ Iowa Soybean Association, Ankeny, Iowa

${ }^{3}$ The Nature Conservancy, Des Moines, Iowa

*corresponding author

(C) 2017. This manuscript version is made available under the Elsevier user license http://www.elsevier.com/open-access/userlicense/1.0/ 


\begin{abstract}
Conservation practices are needed to reduce the loss of nitrate via subsurface tile drainage systems and in this study we evaluated nitrate retention in a reconstructed oxbow in central Iowa that was engineered to receive inputs from two drainage tiles. Our objectives were to evaluate the hydrogeology and nitrate loading patterns and quantify the average and seasonal nitrate retention efficiency in the reconstructed oxbow. Over a two-year period, water and nitrate concentrations and loads into the oxbow were dominated by tile drainage inputs compared to groundwater seepage. Nitrate concentrations were highest in tile drainage water ( 9 to $17 \mathrm{mg} / \mathrm{l}$ ), similar in upgradient groundwater and in the oxbow itself (4-8 $\mathrm{mg} / \mathrm{l})$ and lowest in downgradient groundwater $(0.2 \mathrm{mg} / \mathrm{l})$. Using $\mathrm{N}: \mathrm{Cl}$ ratios, we estimated nitrate retention efficiency from May to September to range from $44 \%$ to $47 \%$ in 2014 and 2015 , respectively, and found that on a monthly basis, greater retention efficiencies were measured in late summer and early fall. The nitrate retention efficiency was similar to other practices such as bioreactors, wetlands and saturated buffers. Given ecosystem benefits of oxbows and similar costs compared to bioreactors, we believe that reconstructing oxbows to receive tile drainage water should be considered a viable practice for tile drainage treatment in agricultural areas.
\end{abstract}

Keywords: Oxbow, wetlands, tile drainage, best management practices, nitrate-nitrogen, nitrate retention 


\section{INTRODUCTION}

Excessive nitrate-nitrogen (nitrate) concentrations and loads from the Midwestern United States are impacting local (USEPA, 2013) and regional water bodies including the Gulf of Mexico (Turner et al., 2008). Recent assessments call for a $45 \%$ reduction in total nitrogen $(\mathrm{N})$ and phosphorus (P) loads to reduce the size of the hypoxic zone in the Gulf (USEPA, 2008) although a 70\% reduction has also been suggested (Liu et al., 2010). In response to this call for action, many states, including Iowa (INRS, 2013), Ohio (Ohio EPA), Illinois (INLRS, 2014) and Minnesota (MPCA, 2014) are developing strategies to reduce export of nitrate from agricultural nonpoint sources through implementation of in-field and edge-of-field best management practices (BMPs).

In many regions, BMPs are needed to reduce the loss of nitrate via subsurface tile drainage systems (Jaynes et al., 2001; Tomer et al., 2003; Schilling et al., 2012). Tile drainage increases the efficiency of nitrate delivery to streams (Robertson and Saad, 2011) and is a major source of nitrate loads to Midwest rivers (McLellan et al., 2015; Schilling et al., 2012). Average nitrate concentrations in tile drainage water beneath corn-soybean rotations often exceed 10-20 mg/l (Ikenberry et al., 2014) and nitrate yields are typically greater than $20-40 \mathrm{~kg} / \mathrm{ha}$ (Jaynes et al., 2001; Ikenberry et al., 2014). McIsaac and Hu (2004) estimated that the 11 million ha of drained cropland in the Mississippi River basin (16\% of the drainage area) contributed $30 \%$ of the nitrate flux in the lower Mississippi River from 1955 to the 1990s. Traditional BMPs for edge-of-field nitrate reduction from tiled systems include bioreactors (Shipper et al., 2010) and wetlands (Tomer et al., 2013), and a promising new BMP is focused on reconnecting tile drainage networks to riparian buffers (Jaynes and Isenhart, 2014). Beyond these practices, McLellan et al. (2015) suggested that BMPs are needed that enhance nutrient processing in stream channels and 
floodplains but noted that data are lacking from floodplain restoration projects in agricultural settings.

Oxbow lakes are formed when a river cuts off a meander loop as it migrates within its floodplain (Wohlman and Leopold, 1957). Over time, natural oxbows may fill with sediment and organic materials and transition from lentic to terrestrial habitat (Piegay et al., 2000; Constantine et al., 2010). They are known to provide important topographic, hydrological and habitat diversity along floodplain corridors (Ward, 1998). Restoration of floodplain oxbows and wetlands is being increasingly recognized for their ability to treat nutrient loads and provide ecosystem services such as flood storage and aquatic habitat (Fink and Mitsch, 2007; Harrison et al., 2014; Mitsch et al., 2014). Oxbows have been the focus of restoration in central Iowa as an innovative fish habitat improvement and nitrate treatment practice (Jones et al., 2015).

Nitrate reduction benefits of oxbows have been quantified by several investigators. Fink and Mitsch (2007) used an engineered "created" oxbow system to quantify the difference in inflow and outflow water quality associated with flood pulses and reported annual nitrate mass reductions of $48 \%$. Mitsch et al. 2014 reported nitrate retention for the same engineered oxbow diversion system for 32 wetland years to be approximately 15.5\%. Harrison et al. (2014) monitored two relict oxbow lakes near an urban environment and reported that the oxbows retained 23 to $87 \%$ of nitrate load that entered the oxbow during four storm events. Using ${ }^{15} \mathrm{~N}$ experiments at the same two sites, Harrison et al.,(2012) estimated that during the summer, plant and algal uptake accounted for 42 to $63 \%$ of the added ${ }^{15} \mathrm{NO} 3$, with the remainder assumed to be lost via denitrification. Garcia-Garcia et al. (2009) used nitrate-chloride ratios to quantify nitrate retention and estimated it to be $72 \%$ for a wetland-stream system dominated by high inflow nitrate concentrations (above $20 \mathrm{mg} / \mathrm{l}$ ). Jones et al. (2015) compared mean nitrate concentrations in three 
oxbows to inlet tile water and found a 45 to $61 \%$ reduction in concentration. These studies indicate that both natural and restored oxbows are capable of retaining a substantial percentage of inflow nitrate.

In this study, we evaluated nitrate retention in a reconstructed oxbow in central Iowa that was engineered to receive inputs from two drainage tiles in addition to seepage from natural groundwater inflow. Our study sought to combine the need to develop new BMPs for tile drainage with the interest in enhancing nutrient processing and habitats in floodplain environments. Specifically, our study objectives were to evaluate the hydrogeology and nitrate loading patterns in the floodplain environment and quantify the average and seasonal nitrate retention efficiency in the reconstructed oxbow. Developing a better understanding of the nitrate retention capacity of the reconstructed oxbow will enable landowners and conservation professionals to incorporate these features in nonpoint source reduction strategies.

\section{METHODS AND MATERIALS}

\section{Site Description}

The Frye oxbow site (named after the landowner) is located along White Fox Creek in Hamilton County, Iowa (Figure 1). White Fox Creek drains a watershed area of approximately 19,500 ha above the monitoring site and it flows downstream into the Boone and Des Moines rivers. White Fox Creek and the Boone River are located within the Des Moines Lobe ecoregion of Iowa, a landscape region of recent glaciation $(<12,000$ years old $)$ containing many drained pothole wetlands (Prior, 1991). Dominant soils include the Canisteo-Nicollet-Webster soil association consisting of silty and loamy soils formed in glacial till and wetlands. Land cover in the White Fox Creek watershed above our oxbow site is dominated by corn and soybeans (87\%). 
Farther downstream, the Des Moines River is a source of municipal drinking water supply for the Des Moines metropolitan area.

In December 2012, the remnant oxbow present at the site was excavated and the remnant oxbow was lengthened and deepened (Figure 2). Approximately 2,071 $\mathrm{m}^{3}$ of post-settlement alluvium was excavated to a depth of approximately 1.8 to $2 \mathrm{~m}$, although the excavation depth was based on reconnecting the oxbow to the coarser-textured alluvium. The bottom was left uneven with 2:1 slopes. The spoils from the excavation was hauled out of the floodplain and spread in a nearby agricultural field. Two 8-in diameter tile lines were already discharging into the legacy oxbow (labeled as north tile (NT) and south tile (ST) in Figure 1) and these were left in place following the excavation. The final design of the oxbow consisted of two 0.08 ha oxbow cells connected by a $2.4 \mathrm{~m}$ long, $0.4 \mathrm{~m}$ deep connective channel. The outlet of the oxbow is connected to the channel of White Fox Creek during high flow events.

Currently the oxbow site is located in a grazed pasture (horses). A row crop field is located approximately $10 \mathrm{~m}$ west of the oxbow (Figure 1).

\section{Field Investigation}

A geophysical survey of the oxbow area was conducted using electrical resistivity (ER) and electromagnetic terrain conductivity (EM) methods. With the ER method, an electrical current is induced into the subsurface through stainless steel electrodes at locations along a transect and the resulting electric potential is used to map the resistivity of the subsurface materials. After processing and inversion of the ER data, results are presented as a two-dimensional model representation of bulk electrical resistivity values (in Ohm-meters) at depth along a surface transect. For EM mapping we used a Geonics EM-31 unit. The EM-31 maps changes in ground conductivity (inverse of resistivity) using an electromagnetic induction technique with an effective 
depth of penetration of approximately $6 \mathrm{~m}$ (www.geonics.com). The EM-31 survey consisted of walking survey lines oriented east-west across the area. Values were recorded with coordinate locations in a continuous manner and stamped with the coordinate locations using a high-precision GPS. The survey points were contoured with the kriging routine in ArcGIS.

Monitoring wells were installed in two three-well transects that straddled the oxbow (Figure 1) using a truck-mounted Geoprobe ${ }^{\mathrm{TM}}$ hydraulic percussion system. The $3.2 \mathrm{~cm}$ diameter wells installed to a depth of $4.5 \mathrm{~m}$ deep and consisted of a $3.0-\mathrm{m}$ well screen a $1.5 \mathrm{~m}$ riser that extended the well above the land surface.

Following well installation, the wells were located with GPS and the top of the casings were surveyed to a site-established benchmark. The wells were developed by surging and overpumping using a Waterra sampling system. Most monitoring wells were sampled on 15 occasions in both 2014 and 2015, noting that in 2015, well S1 was damaged and was only sampled five times. An Onset ${ }^{\circledR}$ Hobo U20 pressure transducer was installed in all of the wells and programmed to measure variations in pressure and temperature at hourly intervals during the study period. Falling head tests were conducted in the wells and results were analyzed using the methods of Bouwer and Rice (1976). Water samples from wells were collected using a peristaltic pump. Water samples were collected as grab samples from the two tiles, oxbow and White Fox Creek on numerous occasions in 2014 and 2015, although the exact number for each location varied from approximately $10-15$ per year.

Discharge in was measured by Isco 2150 Area Velocity (AV) Flow Modules. AV sensors were secured to expansion rings placed approximately 2 meters into the tiles from the outlet. The AV sensors use a pressure transducer to measure water depth and ultrasonic sound waves to measure water velocity. Measurements were stored in the module at 5 minute increments and used to 
calculate tile discharge. Ultrasonic velocity measurements require particles or bubbles in the water to reflect the waves back toward the sensor. Sensors were calibrated by the factory prior to installation, and calibrated to a staff gauge quarterly following installation. Tile water is generally clear so many velocity measurements were not detected, especially at lower flows. For this analysis, measurements of depth without a corresponding velocity measurement or a spurious negative value were deleted and the remaining values used to calculate a daily mean discharge. Precipitation data was obtained from the U.S. National Weather Service (NWS) station at Webster City, Iowa (http://weather.noaa.gov/weather/current/KEBS.html), located about $10 \mathrm{~km}$ from the sample locations.

\section{Water quality sampling and analysis}

Water samples from the Frye oxbow site were hand-delivered to the Iowa Soybean Association laboratory on the day of collection. The Iowa Soybean Association maintains a certified testing laboratory in Ankeny, Iowa. Samples were immediately analyzed on the day of collection using Environmental Protection Agency method 300.0 (National Environmental Methods Index 2008a). Quality assurance/quality control procedures including blanks, fortified samples (spikes), replicates, and known concentration samples, were analyzed with each analytical batch. Concentrations of $\mathrm{NO} 3-\mathrm{N}$ and $\mathrm{Cl}$ are reported as $\mathrm{mg} / \mathrm{l}$.

\section{Nitrate Retention Calculations}

Nitrate-chloride $(\mathrm{N}: \mathrm{Cl})$ ratios in input water to the oxbow were compared to $\mathrm{N}: \mathrm{Cl}$ ratios in the oxbow itself to estimate nitrate retention in 2014 and $2015 . \mathrm{Cl}$ is a conservative tracer that does not undergo transformation or removal in solutions, so variations in $\mathrm{Cl}$ concentrations track water flow and the combined effects of dilution, dispersion and diffusion processes. Loss of $\mathrm{N}$ relative to $\mathrm{Cl}$ concentrations suggests removal of $\mathrm{N}$ from the aqueous system from biophysical processes 
such as assimilation or denitrification (e.g., Simmons et al., 1992; Sabater et al., 2003; GarciaGarcia et al., 2009).

Monitoring data were used to develop an estimate of daily $\mathrm{N}$ and $\mathrm{Cl}$ loading to the oxbow from tile discharge, groundwater flow and precipitation. Mean daily tile discharge into the oxbow from the north $\left(\mathrm{T}_{\mathrm{N}}\right)$ and south $\left(\mathrm{T}_{\mathrm{S}}\right)$ tiles was used along with periodic grab samples to estimate daily $\mathrm{N}$ and $\mathrm{Cl}$ input loads. For all cases with periodic grab samples, linear interpolation was used to estimate concentrations on unmeasured days. The rate of groundwater flow into the oxbow was estimated from Darcy's Law:

$\mathrm{V}=-\mathrm{Ki} / \mathrm{n}$

Where $\mathrm{K}$ is the hydraulic conductivity $(\mathrm{m} / \mathrm{s}), \mathrm{i}$ is the hydraulic gradient and $\mathrm{n}$ is effective porosity. We derived the mean hydraulic gradient across the oxbow using the continuously monitored water table levels. The average $\mathrm{K}$ of the aquifer was estimated using slug tests and assuming an effective porosity of 0.25 for the alluvium. The rate of groundwater flow (v) was multiplied by the upgradient saturated thickness of the oxbow (136 $\mathrm{m}$ long and $1 \mathrm{~m}$ water depth) to estimate the daily groundwater discharge rate into the oxbow. $\mathrm{N}$ and $\mathrm{Cl}$ concentrations measured at wells $\mathrm{N} 1$, S1 and S2 were used to estimate input groundwater loading rates. Monthly precipitation concentrations were obtained from the National Atmospheric Deposition Program for their monitoring site in Chariton, Iowa (http://nadp.sws.uiuc.edu/). Daily concentrations were interpolated from the monthly data and combined with daily precipitation to estimate precipitation loading of $\mathrm{N}$ and $\mathrm{Cl}$ into the oxbow. Overall, daily $\mathrm{N}$ and $\mathrm{Cl}$ loads into the oxbow were calculated as

Daily $\mathrm{N}$ or $\mathrm{Cl}$ input loads $(\mathrm{kg} /$ day $)=\Sigma\left(\mathrm{T}_{\mathrm{N}}+\mathrm{T}_{\mathrm{S}}+\mathrm{GW}+\mathrm{P}\right)$ 
Daily nitrate retention efficiency (\%R) was calculated using the equation (Garcia-Garcia et al., 2009):

$\% \mathrm{R}=\left(1-\left(\mathrm{N} / \mathrm{Cl}_{\mathrm{ox}} / \mathrm{N} / \mathrm{CL}_{\text {in }}\right) \times 100\right.$

Where $\mathrm{N} / \mathrm{Cl}_{\mathrm{ox}}$ is the daily ratio measured in the oxbow and $\mathrm{N} / \mathrm{CL}_{\text {in }}$ is the daily $\mathrm{N} / \mathrm{Cl}$ ratio of total daily $\mathrm{N}$ and $\mathrm{Cl}$ loads into the oxbow. \% $\mathrm{R}$ is the percentage of the inflow $\mathrm{N}$ load removed by the oxbow. We were unable to reliably measure surface water discharge from the oxbow to White Fox Creek nor follow the groundwater discharge pathway beneath the oxbow so we were unable to close the $\mathrm{N}$ and $\mathrm{Cl}$ balance for the oxbow during the project period.

\section{RESULTS}

\section{Site Characterization}

The geology of the monitoring site was characterized vertically and spatially using geophysical methods. The ER survey was conducted along two transects across the oxbow area from the edge of an agricultural field to the stream (Figure 3). The resistivity of the sediments ranged from approximately 25 to 300 ohms-m and based on correlations established at other sites, we interpreted the variations to reflect different geologic materials (Figure 3). In the north transect, approximately 1.5 to $4.5 \mathrm{~m}$ of sandy loam overlies loam and a thick sand deposit associated with the point bar of the modern floodplain occurs in the eastern portion of the transect (Figure 3). In the south transect, loam overlies sand deposits and a smaller region of sand is located adjacent to the White Fox Creek. The EM mapping identified a region of higher ground conductivity (>15 $\mathrm{mS} / \mathrm{m}$ ) in the northwest portion of the site and lower conductivity in the eastern portion near the stream $(<10 \mathrm{mS} / \mathrm{m})$ (Figure 3). Higher conductivity is indicative of a greater fraction of silt and clay in the sediment whereas sand is typified by low conductivity. The EM survey suggests that the northwest portion of the site upgradient of the oxbow is less permeable (greater fines) than the 
sandy floodplain near the stream. Results from the EM and ER surveys are consistent and indicate subsurface variations in aquifer material ranging from sand to loam.

\section{Hydrology}

Annual precipitation measured nearby in Webster City, Iowa, was similar in 2014 (1001 mm) and 2015 (1081 mm) but both periods experienced episodic rainfall (Figure 4). During a two week period in late June 2014, approximately $241 \mathrm{~mm}$ of rainfall fell in Webster City, with daily totals of $72 \mathrm{~mm}$ and $52 \mathrm{~mm}$ occurring on June 17 and June 30, respectively. In 2015, less rainfall occurred in the spring and the largest single day event occurred in late August $(83 \mathrm{~mm})$. In particular, the August 2015 period was very wet $(248 \mathrm{~mm})$ and more than double the normal monthly rainfall total for the region.

Tile discharge combined from the north and south tiles followed rainfall patterns (Figure 4). In response to $72 \mathrm{~mm}$ rainfall on June 17,2014 , tile flow into the oxbow increased from $31 \mathrm{~m}^{3} /$ day to $3,066 \mathrm{~m}^{3} /$ day over a three day period, decreased quickly to $138 \mathrm{~m}^{3} /$ day before increasing again to $3,603 \mathrm{~m}^{3} /$ day following $136 \mathrm{~mm}$ of additional rainfall. From the peak tile discharge in late June, tile discharge steadily decreased through the remainder of the monitoring season to rates less than $5 \mathrm{~m}^{3} /$ day in August and September. In 2015, tile discharge in excess of $950 \mathrm{~m}^{3} /$ day were measured in late June and late August (Figure 4). Overall, average tile discharge was higher in 2014 than $2015\left(176 \mathrm{~m}^{3} /\right.$ day and $149 \mathrm{~m}^{3} /$ day, respectively) but median discharge was higher in 2015 (63 $\mathrm{m}^{3} /$ day and $116 \mathrm{~m}^{3} /$ day, respectively).

Water table depths varied throughout the monitoring period (Figure 4). In 2014 at the N1 well, the water table depth ranged from 0.26 to $1.32 \mathrm{~m}$ below ground surface and averaged $1.11 \mathrm{~m}$. The largest fluctuation in water table depth occurred in late June 2014 during the excessive rainfall period. In 2015 , water table depths fluctuated less $(0.82$ to $1.31 \mathrm{~m})$ and averaged approximately 
the same depth as $2014(1.10 \mathrm{~m})$. Other wells monitored during the project exhibited similar water table fluctuations and depths.

Groundwater at the site generally flows from the west to the east across the oxbow but the flow system becomes more complex in the floodplain nearer to White Fox Creek (Figure 1). Based on hydraulic gradients, the groundwater flow direction is consistently from wells N1 to N2 and from wells S2 to S3 across the oxbow, but within the meander bend, there is evidence that groundwater flow direction turns more north to south as it becomes influenced by subsurface flow induced by White Fox Creek (Figure 1). The subsurface flow pathway from White Fox Creek into the aquifer is consistent with patterns of coarser textured alluvium delineated with the geophysics (Figure 3). Although the exact nature of the groundwater flow system cannot be resolved with our current well configuration, it is sufficient for our study that groundwater enters the oxbow from the west and exits to the east (Figure 1).

The daily horizontal hydraulic gradient was calculated based on continuous water level measurements and it averaged 0.014 in 2014 and 0.015 in 2015 across the transect of wells. Based on slug tests, the hydraulic conductivity of the alluvium was estimated to be $0.12 \mathrm{~m} / \mathrm{day}$. If we assume that groundwater enters the oxbow across a 1-m saturated depth along the $136 \mathrm{~m}$ long upgradient (western) edge, groundwater discharge into the oxbow averaged approximately 0.24 $\mathrm{m}^{3} /$ day in 2014 and $0.25 \mathrm{~m}^{3} /$ day in 2015 . Hence, during the study periods, groundwater flow contributed significantly less average daily discharge to the oxbow compared to the tile discharge $(\sim 0.2 \%)$

\section{Water Quality}

Water samples collected from tiles, groundwater wells, oxbow and White Fox Creek showed variable nitrate and chloride concentrations in 2014 and 2015 (Table 1). Highest nitrate 
concentrations were detected in tiles discharging to the oxbow (mean ranging from 9 to $17 \mathrm{mg} / \mathrm{l}$ ) and in White Fox Creek (12-16 mg/l), whereas upgradient groundwater and oxbow concentrations were similar $(4-8 \mathrm{mg} / \mathrm{l})$ and downgradient groundwater concentrations were lowest $(0.2 \mathrm{mg} / \mathrm{l})$. Nitrate concentrations at all locations were higher in 2014 than in 2015. Chloride concentrations were typically higher than nitrate concentrations at the monitoring sites although both constituents had relatively high standard deviations (Table 1).

Nitrate concentrations varied temporally during the 2014 and 2015 monitoring periods (Figure 5). Concentrations fluctuated in response to episodic precipitation inputs in 2014, with peak well concentrations at N1 corresponding to May and June rainfall inputs. During this period, tile concentrations remained elevated, with nitrate in the north tile often $>20 \mathrm{mg} / \mathrm{l}$. In contrast, during 2015, a general pattern of decreasing nitrate concentrations through the season was evident (Figure 5). Oxbow concentrations typically followed a pattern similar to the tiles.

Nitrate loads into the oxbow were dominated by tile discharge (Figure 6). In 2014, the cumulative nitrate load into the oxbow increased from $36 \mathrm{~kg}$ on June 21 to $414 \mathrm{~kg}$ by July 3 and then increased gradually to $470 \mathrm{~kg}$ by the end of monitoring period. In contrast, the groundwater nitrate load showed more gradual loading throughout the year and reached a modest $0.15 \mathrm{~kg}$ at the end of 2014 monitoring. In 2015, nitrate loads into the oxbow were dominated by the tiles, but the cumulative loading pattern was similar for both tiles and groundwater (Figure 6).

\section{Nitrate Retention Efficiency}

The daily nitrate retention efficiency varied throughout 2014 and 2015 (Figure 7). In 2014, the retention efficiency increased to the end of June, then decreased with the large hydraulic loading occurring at the end of June. Following this influx of $\mathrm{N}$ loads, the efficiency increased through the end of September with minor fluctuations due to occasional rainfall-induced minor $\mathrm{N}$ 
loading events. In 2015, the nitrate retention efficiency was approximately $20 \%$ until mid-July, then increased substantially to near $100 \%$ in late August before decreasing due to a large loading event in early September (Figure 7). Despite different temporal loading patterns, the mean nitrate retention efficiency for both years was similar. For the entire period of monitoring in 2014 (May 20 to October 1) the retention efficiency was $44 \%$. In 2015 , when monitoring occurred over a longer time period that included cooler spring months (March 25 to September 9), the retention efficiency was $41 \%$. During an overlapping May to September period, the efficiency was $44 \%$ and 47\% in 2014 and 2015, respectively. On a monthly basis, greater retention efficiencies was measured in late summer and early fall (Figure 8). Maximum monthly retention values were $92 \%$ and 78\% in August and September 2015.

\section{DISCUSSION}

Study results indicated that a reconstructed floodplain oxbow can efficiently remove nitrate loads delivered to it from tile drainage and groundwater seepage. During two years characterized by very different seasonal nitrate loading inputs, the oxbow retained 44 to $47 \%$ of the nitrate from May to September. The retention efficiency estimated at our oxbow site is consistent with other oxbow studies. Garcia-Garcia et al. (2009) reported that the mean nitrate retention efficiency was 72.3\% for two oxbows in Spain. Fink and Mitsch (2007) measured annual nitrate retention to be $48 \pm 3 \%$ in a created oxbow receiving streamflow diversions. Over a longer term period, the same oxbow diversion had lower nitrate retention (15.5\%; Mitsch et al., 2014). Harrison et al. (2014) reported the percent retention of nitrate loads delivered to two oxbows during storm events ranged from 23 to $87 \%$. Nitrate removal rates ranging from 53-98\% were estimated for a floodplain diversion wetland in Illinois (Kadlec, 2010). 
Nitrate retention in the reconstructed oxbow receiving tile drainage is similar to tile-fed wetlands. Tanner et al. (2005) found nitrate mass removal to range from 11 to $49 \%$ in a study of a constructed wetland treating subsurface drainage water, Kovacic et al. (2000) reported annual percent nitrate removal for three Illinois wetlands ranging from 33 to 55\%, whereas Crumpton et al. (2006) reported nitrate removal rates of 25 to $78 \%$ for three Iowa wetlands. As part of the Iowa Conservation Reserve Enhancement Program (CREP), wetland restorations for nitrate reduction with a 200:1 to 50:1 watershed/wetland ratio are approved for the program. Although we do not know the drainage area for the tiles feeding the oxbow, we estimate it to range from approximately 8 to 18 ha based on flow rates compared to other monitored sites where tile drainage extent is known. Based on surface area of the oxbow ( 0.16 ha), it would have a drainage area to "wetland" ratio of 50:1 to 112:1 which is consistent with CREP recommendations. Overall, the percent nitrate reduction estimated for the Frye oxbow site is similar to reduction rates reported for oxbows and wetlands receiving agricultural $\mathrm{N}$ loads. Differences in removal efficiencies among sites are due to many factors including scale, landscape position, geographic location, loading rates, residence time, concentrations, temperatures, and wetland to watershed ratios (Crumpton et al., 2008).

Our monitoring data is insufficient to discern the processes responsible for nitrate removal in the oxbow, but denitrification and assimilation are considered the dominant mechanisms at other sites (e.g., Garcia-Garcia et al., 2009; Harrison et al., 2012; Hansen et al., 2015). Harrison et al. (2012) conducted ${ }^{15} \mathrm{~N}$ additions during the spring and summer at two oxbows and found that the relative contributions of denitrification and assimilation varied by season. Denitrification accounted for $38-57 \%$ of ${ }^{15} \mathrm{~N}$ transformation in the summer when vegetative assimilation was active and 86-97\% in the early spring when assimilation was less important (Harrison et al, 2012). 
Similarly, Kreiling et al. (2011) reported that the majority of nitrate lost in an upper Mississippi backwater lake during a summer period was due to denitrification (82\%) and Hansen et al. (2014) estimated that $61 \%$ of the nitrate loss was from denitrification and $38 \%$ was associated with assimilation in an Iowa reservoir.

At our oxbow site, seasonal patterns of nitrate retention in 2015 suggest denitrification may be working throughout the year including periods in the spring (April-May) period when assimilation was likely minimal. During the spring, nitrate retention was $\sim 20 \%$, whereas later in the season, nitrate retention increased to $70-100 \%$ when water temperatures are higher and both assimilation and denitrification processes were active. Denitrification has been shown to remove nitrate in created oxbows year-round, even in cold climates (Harrison et al., 2012; Phipps and Crumpton, 1994). Differences in summer and winter denitrification rates were not detected in a relict oxbow in Maryland (Harrison et al., 2012). In 2014, nitrate removal efficiency was increasing from May through early June until a pulse of high nitrate loads was delivered to the oxbow through the tiles in late June and early July. Following the nitrate loading, removal efficiency increased in AugustSeptember from denitrification and assimilation processes. The late summer-early fall time period coincides with greater nitrate removal in streams when warm-water and low-flow conditions lead to greater nutrient removal (Royer et al., 2004). Garcia-Garcia et al. (2009) similarly found nitrate removal efficiency in oxbows increased in the summer months in response to optimal hydrologic conditions that favored biological uptake and denitrification.

Denitrification efficiency in a wetland depends on the denitrification rate and water residence time (Speiles and Mitsch, 2000; Harrison et al., 2012). Although we did not measure denitrification rates, the water residence for nitrate and chloride in the oxbow can be estimated if we assume no water loss at the oxbow outlet and minimal loss of nitrate and chloride to the aquifer: 
Residence time $($ days $)=$ Oxbow $\mathrm{N}($ or $\mathrm{Cl})$ loads $(\mathrm{kg}) / \Sigma(\mathrm{T}+\mathrm{GW}+\mathrm{P})($ in $\mathrm{kg})$

where $\mathrm{T}$ is daily tile $\mathrm{N}$ or $\mathrm{Cl}$ loads, $\mathrm{GW}$ is daily groundwater $\mathrm{N}$ or $\mathrm{Cl}$ loads and $\mathrm{P}$ is daily precipitation $\mathrm{N}$ or $\mathrm{Cl}$ loads. From this estimate, the average residence time for $\mathrm{N}$ and $\mathrm{Cl}$ in the oxbow in 2014 was 3.2 and 5.8 days, respectively, and in 2015, the average residence time was 2.2 and 7.2 days, respectively. Based on these calculations, the residence time for nitrate in the oxbow was $44 \%$ less than $\mathrm{Cl}$ in 2014 and $69 \%$ less in 2015 . The shorter residence for nitrate in the oxbow implies that it is being preferentially removed relative to chloride. At a relict oxbow site in Maryland, Harrison et al. (2012) found that sediment denitrification rates could remove approximately $25 \%$ of the nitrate standing stock in the overlying water column and result in complete removal of any nitrate that entered the wetland with a residence time of $\sim 4$ days. While we cannot verify these statements with our data set, the mean residence time for nitrate relative to chloride at the Frye oxbow site are consistent with these observations. Provided the residence time is long enough (i.e., several days), denitrification in the oxbow sediments may have the potential to remove a substantial amount of nitrate.

Unique to our study of oxbow nitrate processing is the contribution of tile discharge into the oxbow. Water and nitrate concentrations and loads from tile drainage dwarfed the contributions from shallow groundwater (Figures 5 and 6). Mean nitrate concentrations ( 9-17 mg/l) measured in tiles draining to the oxbow were typical for Iowa tile drainage systems (e.g., Tomer et al., 2003; Ikenberry et al. 2014). For example, Ikenberry et al. (2015) reported mean annual concentrations ranging from 10.6 to $31.8 \mathrm{mg} / \mathrm{l}$ over a five-year period in three central Iowa drainage districts. Likewise, since streams in the Des Moines Lobe region of Iowa are largely fed by tile drainage (Schilling et al., 2012), nitrate concentrations in White Fox Creek were similar to concentrations measured in the oxbow tiles. In contrast, mean annual nitrate concentrations in the oxbow were 
61-64\% lower than those found in tiles and shallow groundwater was 40-51\% lower than tiles. The concentration reduction in reconstructed oxbows was highlighted in Jones et al. (2015) who reported concentration reductions ranging from 45 to $62 \%$ compared to tile inlet water at other Iowa locations.

Groundwater nitrate loads to the oxbow were significantly less than tile contributions and it is conceivable that without the tile water contribution, the oxbow would have removed the entire nitrate load discharged with shallow groundwater. Although we were not able to follow groundwater flow paths downgradient from the oxbow in great detail, nitrate concentrations were less than $0.5 \mathrm{mg} / \mathrm{l}$ in the floodplain despite geophysical evidence for subsurface connectivity to White Fox Creek (Figure 3). Low nitrate concentrations are often found in floodplains covered with perennial vegetation. For example, Schilling et al. (2015) reported low groundwater nitrate concentrations $(<0.7 \mathrm{mg} / \mathrm{l})$ in the floodplain of the Cedar River in Iowa under land covers consisting of cool-season grass and woods. Denitrification is as an important biogeochemical process in floodplain soils (Pinay et al., 2007; Forshay and Stanley, 2005) and Schilling et al., (2015) hypothesized that localized denitrification may be occurring within the fine-textured sediments in the floodplain where biogeochemical conditions are favorable. We suspect that the textural heterogeneity within the floodplain depositional environment of White Fox Creek is serving to provide geologic conditions needed for enhanced biogeochemical activity. Hence, any residual nitrate loss from the oxbow via groundwater seepage is likely being reduced to a greater degree in the floodplain.

However, it is evident that a source of uncertainty in our study is that we did not account for outflow of water from the oxbow either through a downstream surface water outfall or in groundwater loss into the aquifer. Because of this, we were unable to follow the nitrate mass and 
complete an $\mathrm{N}$ budget for the oxbow. Despite this limitation, we were able quantify inflows to the oxbow with accuracy and compare $\mathrm{N}: \mathrm{Cl}$ ratios in the measured inlet loads (tiles, groundwater, precipitation) to the standing water in the oxbow to estimate nitrate retention. Assuming that $\mathrm{Cl}$ concentrations adequately tracked water flow and the combined effects of dilution, dispersion and diffusion processes, the percent nitrate retention estimated for the oxbow was reasonable. In 2016, a downstream weir was installed in the oxbow to measure surface water losses to the stream and flow measured at the weir will be used to estimate oxbow outflows in ongoing research. Hydrologic loss via groundwater seepage is unaccounted for in some oxbow studies (Harrison et al., 2012) but in coarse-textured floodplain sediments, this pathway may be significant. More work will be conducted at the Frye oxbow site to resolve the groundwater flow directions in the floodplain. Finally, we note that our study focused on nitrate since this N-species dominates $\mathrm{N}$ export in agricultural areas (Goolsby and Battaglin, 2001), but others have examined the retention capacity associated with other $\mathrm{N}$ forms (Garcia-Garcia et al., 2009). Effects of oxbow retention on total organic nitrogen (TON) and ammonium (NH4-N) are mixed but they typically act at sinks for TON and sources for NH4-N (Garcia-Garcia et al., 2009).

Many other studies of nutrient retention in oxbows have focused on their ability to process $\mathrm{N}$ delivered by flood pulses (e.g., Harrison et al., 2014; Fink and Mitsch, 2007) or as flow-through systems connected to streams (e.g., Garcia-Garcia et al., 2009; Mitsch et al., 2014). Our site differs from these studies by focusing on nitrate removal in an oxbow primarily fed by tile drainage. The nitrate retention of the oxbow $(\sim 45 \%)$ is consistent with other BMPs designed for reducing nitrate in tile drainage water. Estimated nitrate reductions from the Iowa Nutrient Reduction Strategy (INRS) for other tile drainage BMPs included bioreactors $(43 \pm 21 \%)$, drainage water management (33 $\pm 32 \%)$, wetlands $(52 \%)$ and saturated buffers $(50 \pm 13 \%)$ (INRS, 2016). Compared to 
bioreactors that are installed below-ground to treat tile drainage water (e.g., Jones and Kult, 2015), achieving similar nitrate retention efficiency with an above-ground oxbow offers several advantages, including important habitat for fishes, especially the endangered Topeka shiner (Notropis topeka) (Bakevich et al., 2013) and waterfowl (LaGrange and Dinsmore, 1989). Jones et al. (2015) reported that landowners have been especially intrigued by the practice since water quality and wildlife responses are measurable and potential sites are typically found on marginal land unsuited for production. The cost of reconstructing floodplain oxbows ( $\$ 10-15,000$ US dollars each) is similar to bioreactor installations in Iowa $(\$ 7-10,000)$ that have been used to treat drainage from about 10 to 40 ha (Iowa State University, 2011) and are much less than typical costs for tile drainage treatment wetlands under the Conservation Reserve and Enhancement Program which can exceed $\$ 400,000$ for treatment of 500 ha of land area (Christianson et al., 2013). Study results suggest that reconstructing floodplain oxbows to intercept tile drainage water should be considered a viable BMP for tile drainage treatment and added to the portfolio of solutions for reducing nitrate loads in agricultural regions.

\section{CONCLUSIONS}

In this study, we evaluated nitrate retention in a reconstructed oxbow in central Iowa that was constructed to receive inputs from two drainage tiles and groundwater seepage. Over a two-year period, water and nitrate concentrations and loads into the oxbow were dominated by tile drainage inputs. Nitrate concentrations were highest in tile drainage water (9 to $17 \mathrm{mg} / \mathrm{l}$ ), similar in upgradient groundwater and in the oxbow itself $(4-8 \mathrm{mg} / \mathrm{l})$ and lowest in downgradient groundwater $(0.2 \mathrm{mg} / \mathrm{l})$. Using $\mathrm{N}: \mathrm{Cl}$ ratios, we estimated nitrate retention efficiency from May to September to range from 44\% to 47\% in 2014 and 2015, respectively, and found that on a monthly basis, greater retention efficiencies were measured in late summer and early fall. We were unable 
to discern the processes responsible for nitrate removal in the oxbow, but denitrification and assimilation are considered the dominant mechanisms at other sites and is likely the case for our study. Overall, the nitrate retention estimate for our reconstructed oxbow fed by tile drainage is similar to efficiencies reported for other engineered or relict oxbows, and is similar to nitrate reductions associated with other tile drainage BMPs such as bioreactors, wetlands and saturated buffers. Given ecosystem benefits of oxbows and similar costs compared to bioreactors, we believe that reconstructing oxbows to receive tile drainage water should be considered a potential BMP for tile drainage treatment in agricultural areas.

\section{ACKNOWLEDGEMENTS}

This project was supported, in part, by the Natural Resources Conservation Service, U.S. Department of Agriculture (Award No. 69-6114-14-008), the Sand County Foundation, and the Iowa Nutrient Research Center (Award No. C6-72746-68). 


\section{REFRENCES}

Bakevich, B.D., Pierce, C.L., and Quist, M.C. 2013. Habitat fish species, and fish assemblage associations of the Topeka Shiner in west-central Iowa. N. Am. J. Fish. Manage. 33:12581268.

Bouwer, H., and Rice, R.C . 1976. A slug test for determining hydraulic conductivity of unconfined aquifers with completely or partially penetrating wells. Water Resourc. Res. 12:423-428.

Christianson, L., Tyndall, J., and Helmers, M. 2013. Financial comparison of sever nitrate reduction strategies for Midwestern agricultural drainage. Water Resourc. Econ. 2-3:30-56.

Constantine, J.A., Dunne, T., Piegay, H., and Kondolf, G.M. 2010. Controls on the alluviation of oxbow lakes by bed-material load along the Sacramento River, California. Sedimentology 57:389-407.

Crumpton, W.G., D.A. Kovacic, D.L. Hey, and J.A. Kostel. 2008. Potential of restored and constructed wetlands to reduce nutrient export from agricultural watersheds in the Corn Belt. p. 29-42. In Final report: Gulf Hypoxia and local water quality concerns workshop. American Society of Agricultural and Biological Engineers, St. Joseph, MI.

Fink, D.F., and Mitsch, W.J. 2007. Hydrology and nutrient biogeochemistry in a created river diversion oxbow wetland. Ecol. Eng. 30:93-102.

Forshay, K.J. and Stanley, E.H. 2005. Rapid nitrate loss and denitrification in a temperate river floodplain. Biogeochemistry 75:43-64.

Garcia-Garcia, V., Gomez, R., Vidal-Abarca, M.R., and Suarez, M.L. 2009. Nitrogen retention in natural Mediterranean wetland-streams affected by agricultural runoff. Hydrol. Earth Syst. Sci. 13:2359-2371.

Goolsby, D.A.and Battaglin, W.A. 2001. Long-term changes in concentrations and flux of nitrogen in the Mississippi River basin, USA. Hydrol. Process. 15:1209-1226.

Hansen, E., Chan, K.S., Jones, C.S. and Schilling, K.E. 2015. Assessing the Relative Importance of Nitrogen-Retention Processes in a Large Reservoir Using Time-Series Modeling. J. Agric. Biol. Environ. Stat. 21:1-18.

Harrison, M.D., Groffman, P.M., Mayer, P.M., Kaushal, S.S., and Newcomer, T.A. 2011. Dentirification in alluvial wetlands in an urban landscape. J. Environ. Qual. 40:634-646.

Harrison, M.D., Groffman, P.M., Mayer, P.M., and Kaushal, S.S. 2012. Nitrate removal in two relict oxbow urban wetlands: a 15N mass-balance approach. Biogeochemistry 111:647-660.

Harrison, M.D., Miller, A.J., Groffman, P.M., Mayer, P.M., and Kaushal, S.S. 2014. Hydrologic controls on nitrogen and phosphorus dynamics in relict oxbow wetlands adjacent to an urban restored stream. J. Am. Wat. Resourc. Assoc. 50:1365-1382.

Ikenberry, C.D., Soupir, M.L., Schilling, K.E., Jones, C.S., and Seeman, A. 2015. Nitrate-nitrogen export: magnitude and patterns from drainage districts to downstream river basins. J. Environ. Qual. 43:2024-2033.

Illinois Nutrient Loss Reduction Strategy (INLRS). 2014. Illinois Environmental Protection Agency, Springfield, IL http://www.epa.state.il.us/water/nutrient/documents/illinois-nlrspublic-comment-11-20-14.pdf (accessed June5, 2015).

Iowa Nutrient Reduction Strategy (INRS) (2013) http://www.nutrientstrategy.iastate.edu/ (accessed March 19, 2013).

Iowa State University, 2011. Woodchip bioreactors for nitrate in agricultural drainage. Iowa State University Extension and Outreach, PMR 1008. 
Jaynes, D.B., and Isenhart, T.M.. 2014. Reconnecting tile drainage to riparian buffer hydrology for enhanced nitrate removal. J. Environ. Qual. 43: 631-638.

Jaynes, D.B., T.S. Colvin, D.L. Karlen, C.A. Cambardella, and D.W. Meek. Nitrate loss in subsurface drainage as affected by nitrogen fertilizer rate. 2001. J. Environ. Qual. 30:13051314.

Jones, C.S. and Kult K. 2016. Use alkalinity monitoring to optimize bioreactor performance. J. Environ. Qual. 45:855-865.

Jones, C.S., Kult, K., and Laubach, S.A. 2015. Restored oxbows reduce nutrient runoff and improve fish habitat. J. Soil Wat. Conserv. 70:49A-52A.

Kadlec, R.H. 2010. Nitrate dynamics in event-driven wetlands. Ecol. Eng. 36:503-516.

Kovacic, D.A., M.B. David, L.E. Gentry, K.M. Starks, and R.A. Cooke. 2000. Effectiveness of constructed wetlands in reducing nitrogen and phosphorus export from agricultural tile drainage. J. Environ. Qual. 29:1262-1274.

Kreiling, R. M., Richardson, W. B., Cavanaugh, J. C., and Bartsch, L. A. 2011. Summer nitrate uptake and denitrification in an upper Mississippi River backwater lake: the role of rooted aquatic vegetation. Biogeochemistry 104:309-324.

LaGrange, T. G., and Dinsmore, J. J. 1989. Plant and animal community responses to restored Iowa wetlands. Prairie Naturalist, 21:39-48.

Liu, Y., Evans, M.E., and Scavia, D. 2010. Gulf of Mexico hypoxia: explaining increased sensitivity to nitrogen loads. Environ. Sci. Technol. 44:5836-5841.

McIsaac G.F., and $\mathrm{Hu}, \mathrm{X}$. . 2004. Net $\mathrm{N}$ input and riverine $\mathrm{N}$ export from Illinois agricultural watersheds with and without extensive tile drainage. Biogeochemistry 70:251-271.

McLellan, E., Robertson, D., Schilling, K., Tomer, M., Kostel, J., Smith, D., and King, K. 2015. Reducing nitrogen export from the corn belt to the Gulf of Mexico: agricultural strategies for remediating hypoxia. J. Am. Wat. Resourc. Assoc. 51:263-289.

Mitsch, W.J., Zhang, L., Waletzho, E., and Bernal, B. 2014. Validation of the ecosystem services of created wetlands: two decades of plant succession, nutrient retention, and carbon sequestration in experimental riverine marshes. Ecol. Eng. 72:11-24.

$\begin{array}{lllll}\text { Minnesota } & \text { Nutrient } & \text { Reduction } & \text { Strategy } & \text { (MNRS). }\end{array}$ http://www.pca.state.mn.us/index.php/view-document.html?gid=20213 (accessed June 5, 2015).

Ohio Nutrient Reduction Strategy (ONRS). 2013. Ohio EPA, division of Surface Water, http://epa.ohio.gov/Portals/35/wqs/ONRS_final_jun13.pdf (accessed June 5, 2015).

Phipps, R.G. and Crumpton, W.G. 1994. Factors affecting nitrogen loss in experimental wetlands with different hydrologic loads. Ecol. Eng. 3:399-408.

Piegay, H., Burnette, G., Herouin, E., Moulin, B., and Statiotis, C. 2000. Channel instability as control factor of silting dynamics and vegetation pattern with perifluvial aquatic zones. Hydrol. Process. 14:3011-3029.

Pinay G., Gumiero, B., Tabacchi, E., Gimenez, O. Tabacchi-Planty, A.M., Helfting, M.M., Burt, T.P., Black, V.A., Nilsson, C., Iordache, V., Bureau, F., Vought, L., Petts, G.E., and DeCamps, H., 2007. Patterns of denitrification rates in European alluvial soils under various hydrological regimes. Freshw. Biol. 52, 252-266.Prior, J.C. 1991. Landforms of Iowa. University of Iowa Press, Iowa City IA, $154 \mathrm{p}$.

Robertson, D. M., and Saad, D. A. 2011. Nutrient inputs to the Laurentian great lakes by source and watershed estimated using SPARROW watershed models1. J. Am. Wat. Resourc. Assoc. 47:1011-1033. 
Royer, T.V., Tank, J.L. and David, M.B. 2004. Transport and Fate of Nitrate in Headwater Agricultural Streams in Illinois. J. Environ. Qual. 33:1296-1304.

Sabater, S., Butturini, A., Clement, J.C., Burt, T., Dowrick, D., Hefting, M., Matre, V., Pinay, G., Postolache, C., Rzepecki, M. and Sabater, F., 2003. Nitrogen removal by riparian buffers along a European climatic gradient: patterns and factors of variation. Ecosystems 6:0020-0030.

Schilling, K.E., Jones, C.S., Seamon, A., Bader E., and Filipiak J. 2012. Nitrate-nitrogen patterns in engineering catchments in the Upper Mississippi River basin. Ecol. Eng. 42:1-9.

Schilling, K.E., Jacobson, P.J. and Vogelgesang, J.A., 2015. Agricultural conversion of floodplain ecosystems: Implications for groundwater quality. J. Environ. Manage. 153:74-83.

Schipper, L.A., Robertson, W.D., Gold, A.J., Jaynes, D.B., and Cameron, S.C. 2010. Denitrifying bioreactors - an approach for reducing nitrate loads to receiving waters. Ecol. Eng. 36:15321543.

Simmons, R.C., Gold, A.J., and Groffman, P.M. 1992. Nitrate dynamics in riparian forest: groundwater studies. J. Environ. Qual. 21:659-665.

Speiles, D.J. and Mitsch, W.J. 2000. The effects of season and hydrologic and chemical loading on nitrate retention in constructed welands. A comparison of low- and high-nutrient riverine systems. Ecol. Eng. 14:77-91.

Tanner, C.C., Nguyen, M.L. and Sukias, J.P.S., 2005. Nutrient removal by a constructed wetland treating subsurface drainage from grazed dairy pasture. Ag. Ecosyst. Environ. 105:.145-162.

Tomer, M.D., Crumpton, W.G., Binger R.L., Kostel, J.A., and James, D.E. 2013. Estimating nitrate load reduction from placing constructed wetlands in a HUC-12 watershed using LiDAR data. Ecol. Eng. 56:69-78.

Tomer, M.D., Meek D.W., Jaynes D.B., and Hatfield J.L. 2003. Evaluation of nitrate-nitrogen fluxes from a tile-drained watershed in central Iowa. J. Environ. Qual. 32:642-653.

Turner, R.E., Rabalais, N.N., and Justic, D. 2008. Gulf of Mexico hypoxia: altered states and a legacy. Environ. Sci. Technol. 42:2323-2327.

United States Environmental Protection Agency (USEPA), 2008. Hypoxia in the Northern Gulf of Mexico, An Update by the EPA Science Advisory Board. EPA, Washington, DC.

United States Environmental Protection Agency (USEPA), 2013. National Rivers and Streams Assessment, 2008-2009, Draft Report. EPA, Washington, D.C.

Ward, J.V. 1998. Riverine landscapes: biodiversity patterns, disturbance regimes, and aquatic conservation. Biol. Conserv. 83:269-278.

Wohlman, M.G. and Leopold, L.B. 1957. River flood plains: some observations on their formation. U.S. Geol. Surv. Prof. Paper 282-C. 


\section{Figure Captions:}

Figure 1. Location of Frye oxbow site along White Fox Creek in north-central Iowa. Sampling sites are identified and approximate shallow groundwater flow directions are shown.

Figure 2. Photographs showing oxbow excavation (top) and oxbow filled with water (bottom).

Figure 3. Geophysical results using electromagnetic terrain conductivity (EM) (top panel) and electrical resistivity (ER) (cross sections).

Figure 4. Summary of hydrologic conditions monitored in 2014 and 2015. Precipitation data from Webster City, IA monitoring station. Tile drainage flux is total from north and south tiles. Groundwater level data from N1 well located upgradient from oxbow.

Figure 5. Nitrate concentrations measured in groundwater, tiles, oxbow and White Fox Creek in 2014 and 2015.

Figure 6. Cumulative nitrate loads from tiles and groundwater into the oxbow in 2014 and 2015.

Figure 7. Nitrate and chloride loading to the oxbow from tiles, groundwater and precipitation and nitrate retention efficiency in 2014 and 2015.

Figure 8. Nitrate retention efficiency by month in 2014 and 2015. 


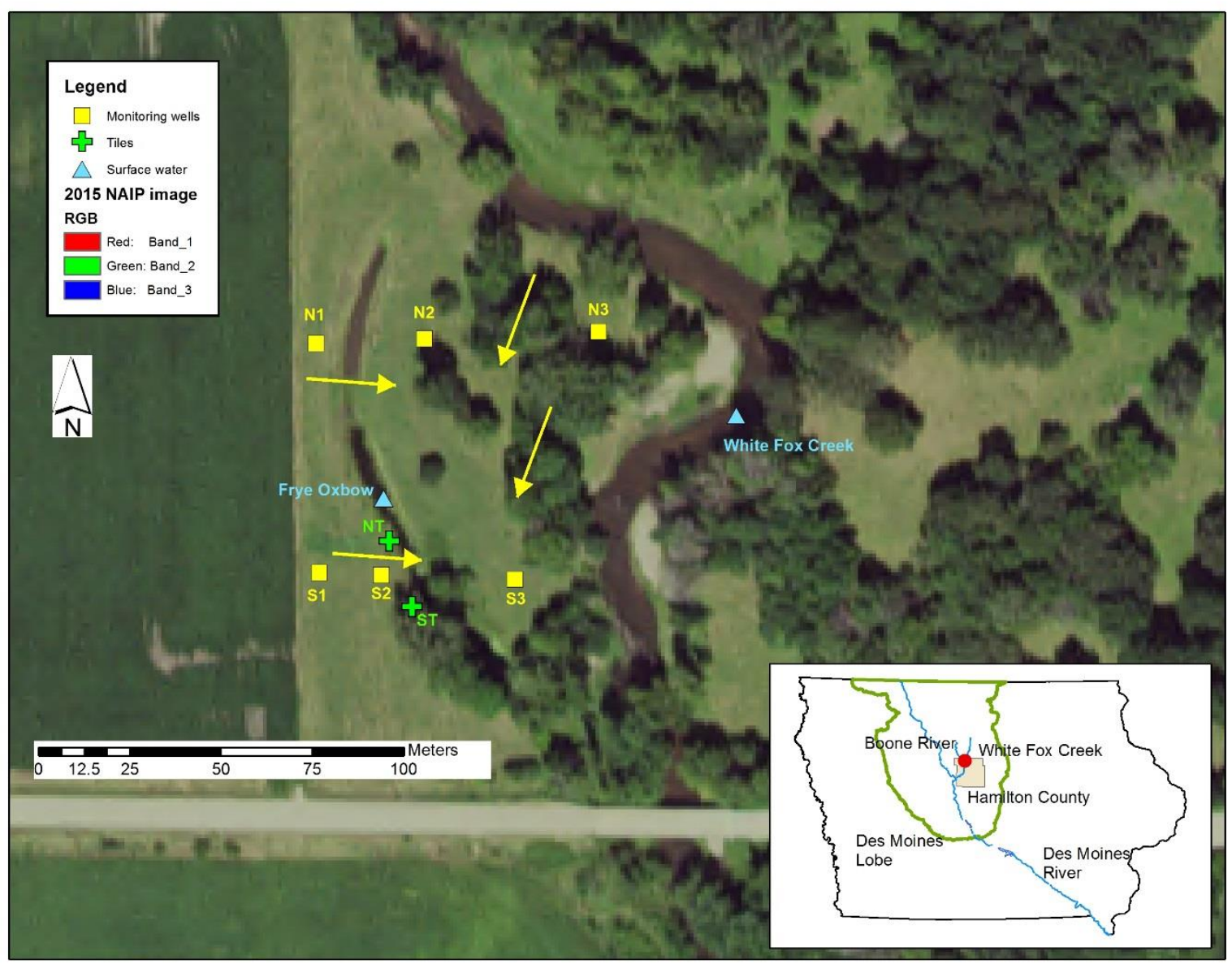



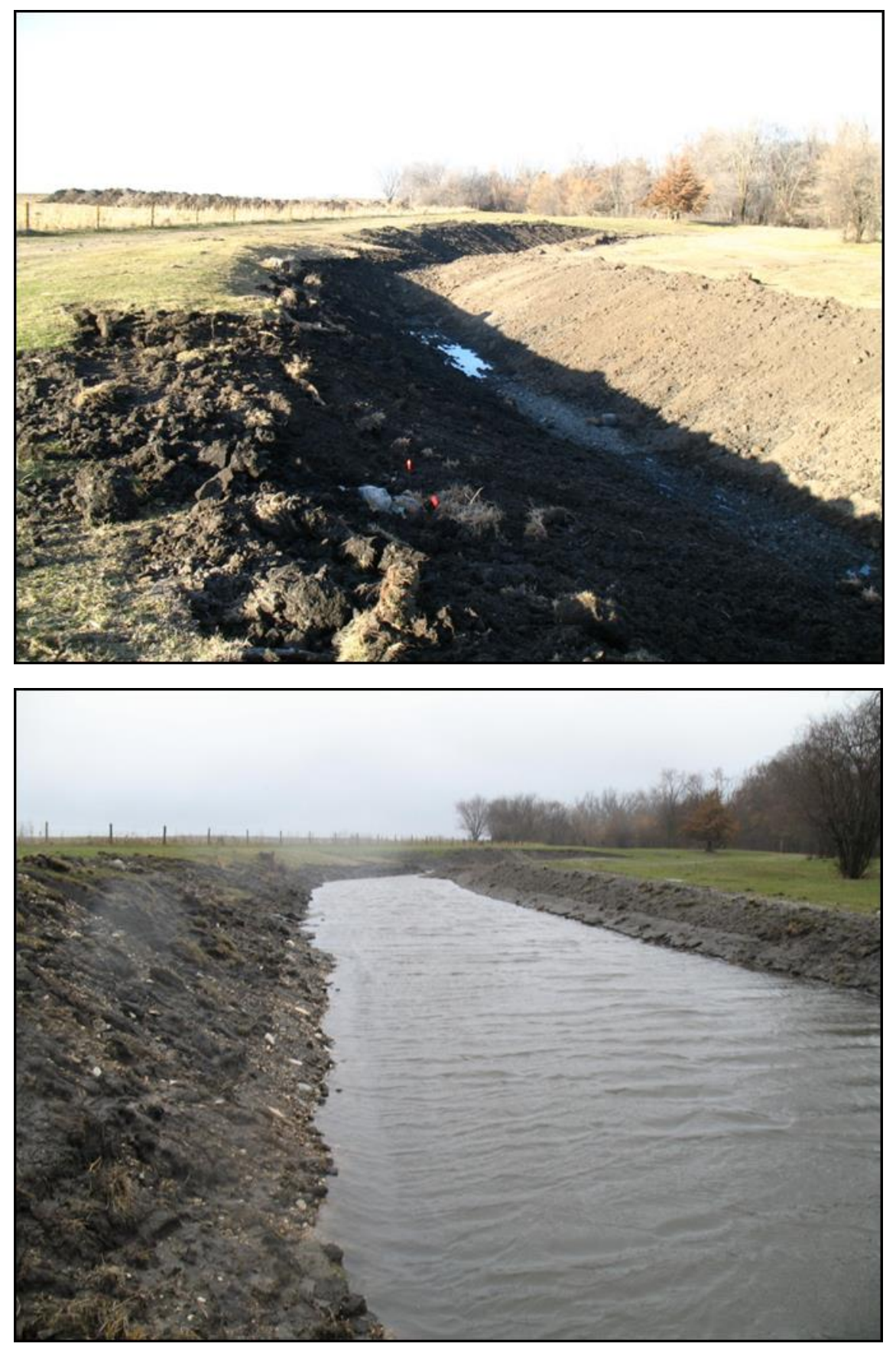

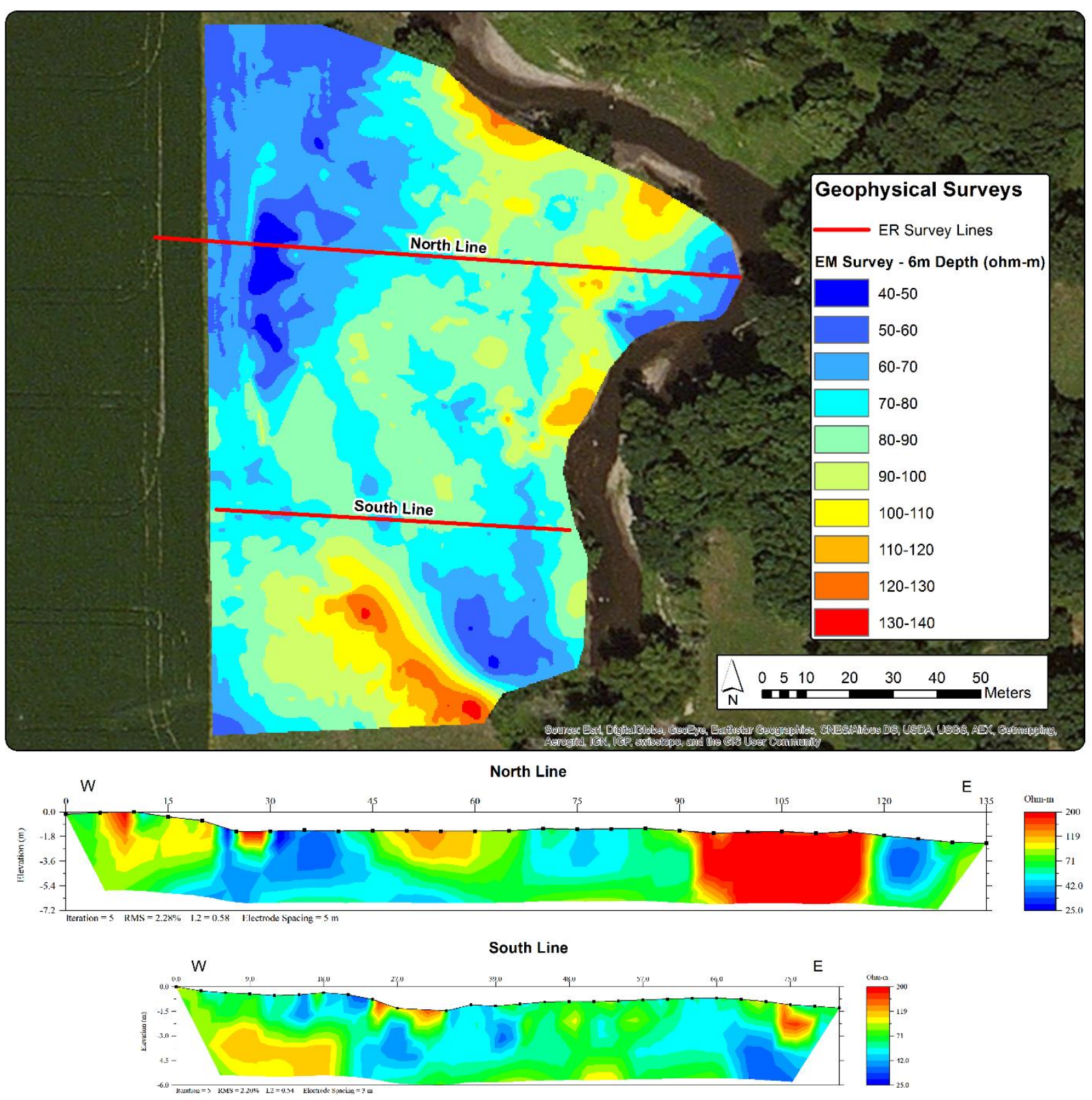

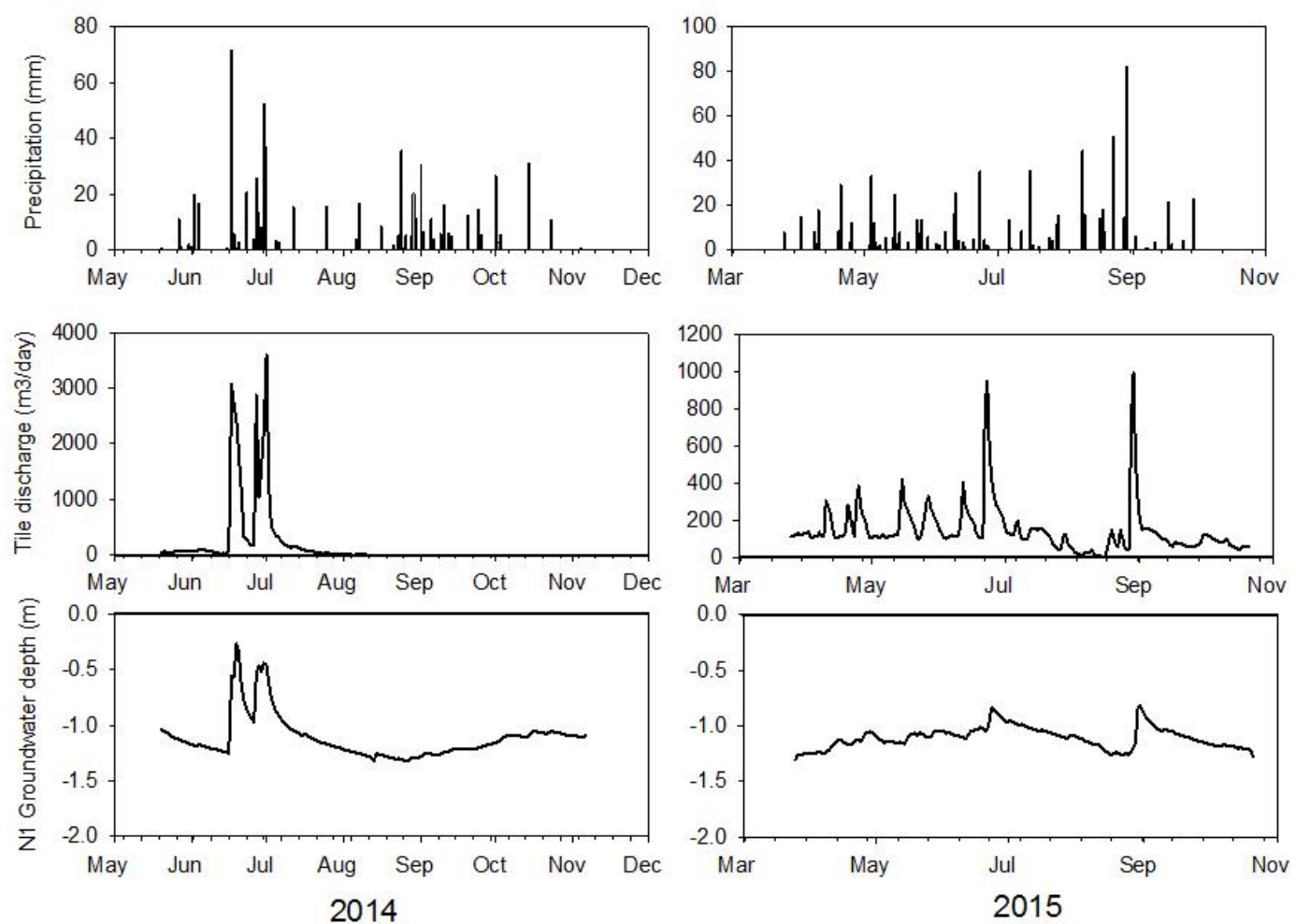

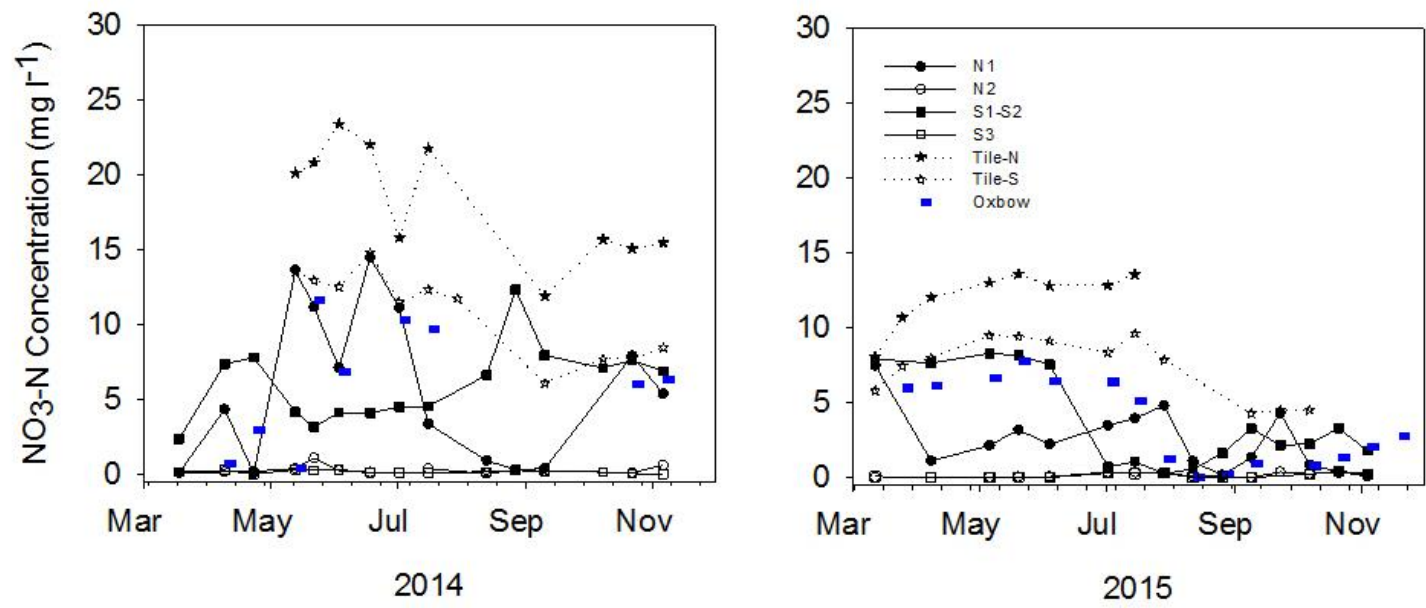

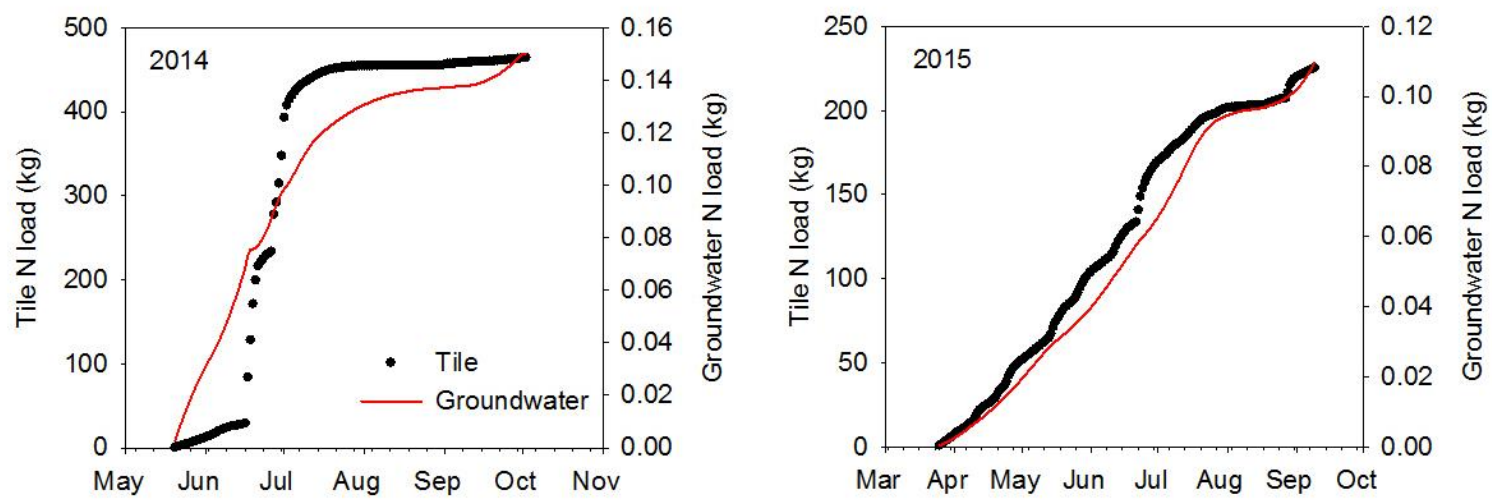

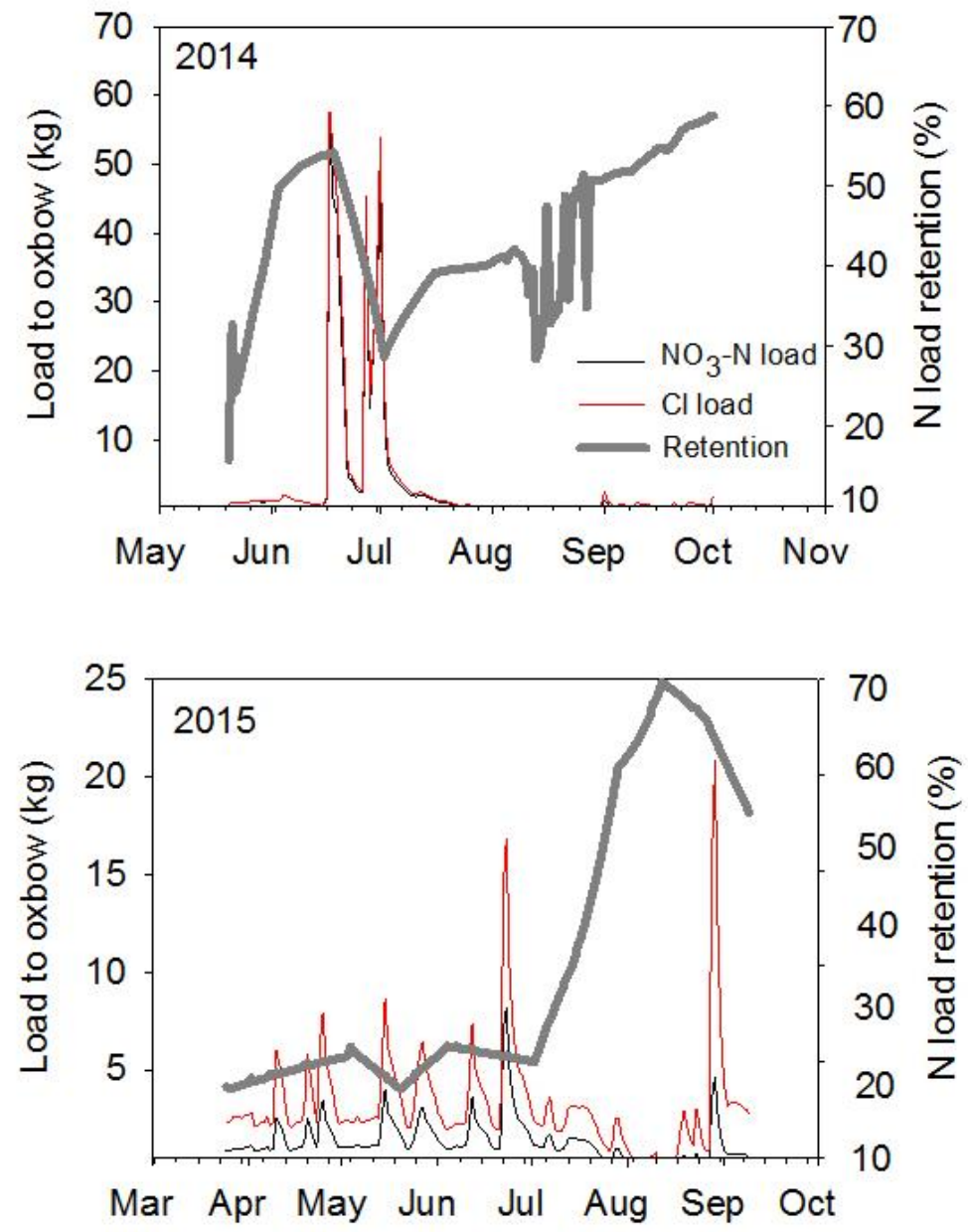


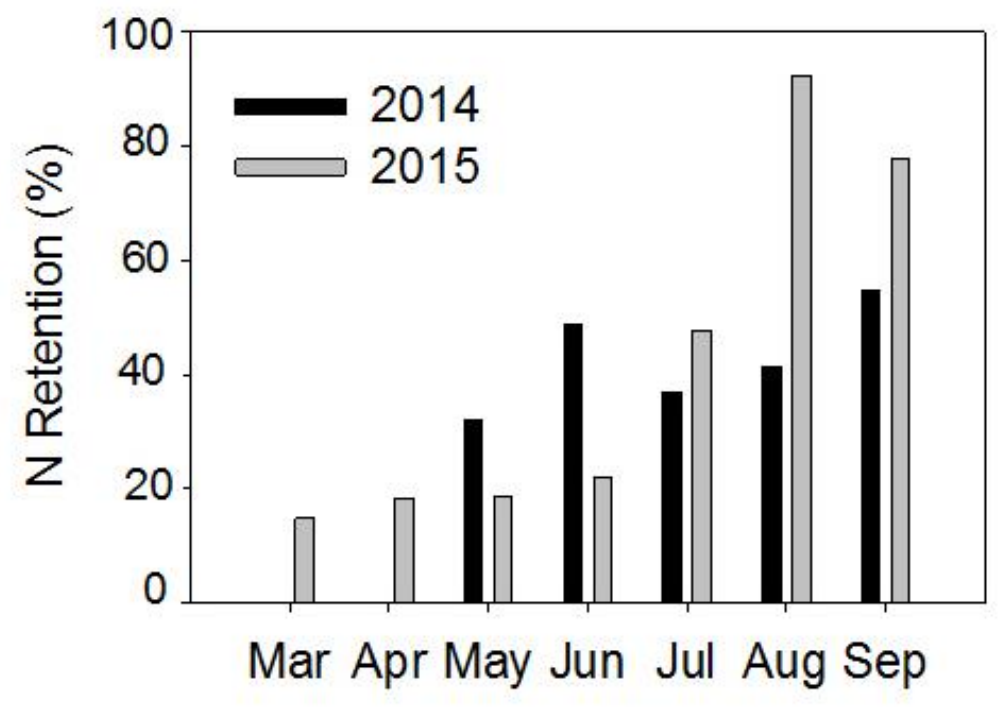


Table 1 . Summary of nitrate and chloride concentrations (mean $\pm \mathrm{sd}$ ) measured at monitoring sites in 2014 and 2015.

\begin{tabular}{|l|l|l|l|l|}
\hline Year & & $\mathrm{n}$ & $\begin{array}{l}\mathrm{NO}_{3}-\mathrm{N} \text { Conc. } \\
(\mathrm{mg} / \mathrm{l})\end{array}$ & Cl Conc. (mg/l) \\
\hline 2014 & Tile & 31 & $16.8 \pm 5.8$ & $17.2 \pm 1.8$ \\
\hline & Influent GW & 29 & $8.3 \pm 5.6$ & $11.6 \pm 8.4$ \\
\hline & Oxbow & 9 & $6.1 \pm 4.1$ & $12.5 \pm 5.0$ \\
\hline & Downgradient GW & 28 & $0.2 \pm 0.2$ & $3.9 \pm 4.9$ \\
\hline & White Fox Creek & 5 & $15.8 \pm 3.4$ & $18.3 \pm 6.0$ \\
\hline & & & & \\
\hline 2015 & Tile & 20 & $9.3 \pm 3.1$ & $19.8 \pm 1.3$ \\
\hline & Influent GW & 20 & $5.6 \pm 5.8$ & $7.9 \pm 5.0$ \\
\hline & Oxbow & 15 & $3.6 \pm 2.8$ & $18.2 \pm 1.4$ \\
\hline & Downgradient GW & 29 & $0.2 \pm 0.2$ & $2.5 \pm 7.3$ \\
\hline & White Fox Creek & 15 & $11.9 \pm 4.9$ & $21.2 \pm 2.8$ \\
\hline
\end{tabular}

${ }^{1}$ Influent groundwater $(\mathrm{GW})$ at wells N1 and S1; ${ }^{2}$ Downgradient groundwater at wells N2 and S3 